\title{
A modified rapid method of nucleic acid isolation from suspension of matured virus: applied in restriction analysis of DNA from an adenovirus prototype strain and a patient isolate
}

\author{
C. T. LE, G. C. GRAY and S. K. PODDAR \\ Naval Health Research Center, DoD Center for Deployment Health Research PO Box 85122, San Diego, CA \\ 92186-5122, USA
}

\begin{abstract}
This report describes a method for the isolation of nucleic acid from a suspension of matured virus. Nucleic acid (DNA) was isolated from a prototype strain of adenovirus type 7 and a clinical isolate of adenovirus type 7 . Instead of the usual method of ultracentifugation, a filtration method was applied to concentrate the virus rapidly and nucleic acid was then isolated by a standard phenol/chloroform/isoamyl-alcohol extraction procedure. The DNA was found to be sufficiently purified to generate a reproducible restriction endonuclease digestion pattern. The clinical isolate of adenovirus type 7 revealed loss of restriction site for the endonuclease HindIII when compared with the prototype strain.
\end{abstract}

\section{Introduction}

Rapid isolation of good quality nucleic acid can greatly facilitate molecular analysis of a viral genome. Hirt's procedure [1] allows isolation of intracellular viral nucleic acids that are still in the process of encapsidation or that are yet to bud out as matured virus. However, host-cell DNA contamination of the isolated intracellular viral nucleic acid sometimes can give rise to unwanted background and can confound molecular biological analysis. Alternatively, viral nucleic acid may be extracted from matured viral suspension $[2,3]$ to reduce the risk of host-cell DNA contamination. However, to obtain nucleic acid in adequate amounts $(1-5 \mu \mathrm{g})$ for molecular biological analysis, the isolation procedure has to be performed with a large volume (at least $20-25 \mathrm{ml}$ ) of matured virus suspension. The usual method requires first pelleting the virus particles from the suspension (cell culture medium) by ultracentrifugation. The pellet is then resuspended in a small volume of extraction buffer and the nucleic acid is extracted from it. An ultracentrifuge is an expensive item and, in many clinical laboratories, neither this equipment nor the appropriate technical personnel to operate it may be available. This report describes a

Received 19 June 2000; revised version accepted 2 Nov. 2000.

Corresponding author: Dr S.K. Poddar (e-mail: poddar@, nhrc.navy.mil). simple, rapid, inexpensive and less technically demanding filtration method of concentrating the virus and transferring it in the desired buffer from the suspension medium (cell culture medium). Also, the quality of DNA isolated from the virus concentrated by this method was examined by restriction endonuclease digestion and analysis of the restriction fragment band patterns by agarose gel electrophoresis.

\section{Materials and methods}

Virus strains

A prototype adenovirus type 7 stock was purchased from the American Type Culture Collection (ATCC, Manassas, VA, USA). A clinical adenovirus type 7 stock (no. 1298, sample collected on 11/10/97) was isolated from a patient with febrile respiratory disease at the Naval Training Center, Great Lakes, IL, USA. Stock viruses were grown in human lung carcinoma A549 cells, a sample of each stock virus was further grown in the same cell line in $75-\mathrm{cm}^{2}$ tissue-culture flasks. Cells were infected according to standard procedure [4] at an approximate multiplicity of infection of 10 . Then, 2-4 days after infection, when maximum cytopathic effect was observed, the medium containing the detached cells and the matured virus was centrifuged in a tabletop centrifuge at $300 \mathrm{~g}$ for $10-15 \mathrm{~min}$. The supernate containing primarily the 
matured virus was collected in a separate container and stored at $4^{\circ} \mathrm{C}$.

\section{Concentration of virus through filtration}

Viral supernate $(20 \mathrm{ml})$ was concentrated with a Centricon Plus-20 filter (Millipore, Bedford, MA, USA) essentially following the manufacturer's suggested procedure for concentrating a macromolecular solution. Briefly, $20 \mathrm{ml}$ of viral suspension was taken in the filter cup of the filter assembly and was placed in the filter collection tube. This was then centrifuged at $4000 \mathrm{rpm}$ in a GS-6R (Beckman, Fullerton, CA, USA) tabletop centrifuge for $20 \mathrm{~min}$. At the end of centrifugation the viral suspension was concentrated to $0.1 \mathrm{ml}$. The cap of the filter cup was removed and $2 \mathrm{ml}$ of buffer A (100 mM Tris, $150 \mathrm{mM} \mathrm{NaCl}, 12.5 \mathrm{~mm}$ EDTA, $\mathrm{pH}$ 7.4) were added. The filter cup was recapped and was placed in another collection tube and centrifuged as before except that the centrifugation time was reduced to $10 \mathrm{~min}$. The addition of buffer $\mathrm{A}$ and subsequent low-speed centrifugation was repeated three or four times to bring the concentrated virus essentially into the ionic environment of buffer A. After the last centrifugation, the filter cup was removed from the collection tube, and the concentrated virus sample was collected in a $1.5-\mathrm{ml}$ microfuge tube from the filter cup with a micropipetter.

\section{Viral DNA extraction}

To $100 \mu \mathrm{l}$ of the above concentrated virus suspension, $100 \mu \mathrm{l}$ of buffer B (100 mM Tris, $150 \mathrm{mM} \mathrm{NaCl}$, $12.5 \mathrm{mM}$ EDTA, pH 7.4, containing SDS 2\%) were added. The mixture was then digested with $4 \mu \mathrm{l}$ of stock proteinase $\mathrm{K}(25 \mathrm{mg} / \mathrm{ml})$ at $50^{\circ} \mathrm{C}$ for $30 \mathrm{~min}$. DNA was then isolated from the solution with two phenol/chloroform and one chloroform/isoamyl-alcohol extraction and subsequent ethanol precipitation. The precipitated DNA was resuspended in $50 \mu \mathrm{l}$ of TE buffer (10 mM Tris, $1 \mathrm{mM}$ EDTA, pH 7.5) containing DNAase-free RNAase $10 \mu \mathrm{g} / \mathrm{ml}$.

\section{Viral DNA extraction by Hirt's procedure}

Viral DNA extraction was performed following essentially the previously published procedure [1]. Briefly, a confluent monolayer of A549 cells infected with the virus was incubated overnight in the tissue culture medium in a $35-\mathrm{mm}$ plate in a $\mathrm{CO}_{2}$ incubator at $37^{\circ} \mathrm{C}$. The next day, if the cells were detached, cells and supernate (medium) were collected in an Eppendorf tube, cells were pelleted by centrifugation in a microfuge for $1 \mathrm{~min}$ and the supernate was discarded. If the monolayer was intact, supernate was removed. Then for each pellet or monolayer of cells, $835 \mu \mathrm{l}$ of a pre-mix solution containing $800 \mu \mathrm{l}$ of Hirt's lysis buffer (SDS $0.6 \%, 0.01 \mathrm{M}$ EDTA, $0.01 \mathrm{M}$ Tris-HCl, pH 7.4) and $35 \mu \mathrm{l}$ of proteinase $\mathrm{K}(15 \mathrm{mg} / \mathrm{ml}$ stock $)$ was added. It was then incubated at $37^{\circ} \mathrm{C}$ for $1 \mathrm{~h}$. The viscous cellular lysate was transferred in an Eppendorf tube and $200 \mu \mathrm{l}$ of $5 \mathrm{M} \mathrm{NaCl}$ were added and mixed gently and then incubated at $4^{\circ} \mathrm{C}$ overnight. The mixture was centrifuged for $20 \mathrm{~min}$ in a microfuge and the supernate was transferred to a fresh Eppendorf tube. Viral DNA was isolated from the supernatant solution by phenol/chloroform/isoamyl alcohol extraction and ethanol precipitation. The precipitated DNA was resuspended in $50 \mu \mathrm{l}$ of TE buffer.

\section{Restriction endonuclease digestion and agarose gel analysis}

Viral DNA from both the prototype and the clinical strain isolated by the method described above and also by Hirt's extraction procedure were subjected to restriction endonuclease digestion and DNA band pattern analysis. DNA solution (10-20 $\mu \mathrm{l}$ : c. $0.5 \mu \mathrm{g})$ was digested with HindIII restriction endonuclease (10 units) in a total volume of $25 \mu \mathrm{l}$ of the appropriate digestion buffer supplied by the manufacturer (New England Biolabs, Beverly, MA, USA) for $2 \mathrm{~h}$ at $37^{\circ} \mathrm{C}$. The digest was then analysed for DNA band pattern by electrophoresis in an agarose $1 \%$ gel in TBE buffer (89 mM Tris-borate, $2 \mathrm{mM}$ EDTA, $\mathrm{pH}$ 8.3) and the DNA bands were visualised by ethidium bromide staining.

\section{Results}

Hin dIII restriction endonuclease digestion of DNA isolated from the matured viral suspension of both the prototype and the clinical isolate no 1298 produced distinct DNA fragment band patterns consisting of 10 and nine fragments, respectively (Fig. 1A). These band patterns were identical to those generated by HindIII digestion of intracellular viral DNA isolated by Hirt's procedure (Figs. 1A and B) [1]. This suggested that the modified procedure generated adequately purified viral DNA from the matured adenoviral suspension.

All DNA fragments but 'a' of the clinical isolate were common to the prototype strain and clinical isolate. The clinical isolate showed fragment ' $a$ ', instead of two smaller fragments (a1 and a2) in the prototype strain, indicating a mutation resulting in the loss of a HindIII site and generating a subtype difference band pattern in the type 7 adenovirus $[5,6]$.

\section{Discussion}

The standard procedure for extraction of DNA from infected cells is labour-intensive and involves timeconsuming disruption of the cells, caesium chloride density gradient centrifugation and dialysis [7]. The extraction method described by Hirt [1] also involves an overnight precipitation of cell genomic DNA with $\mathrm{NaCl}$ and, therefore, does not allow a rapid isolation of 

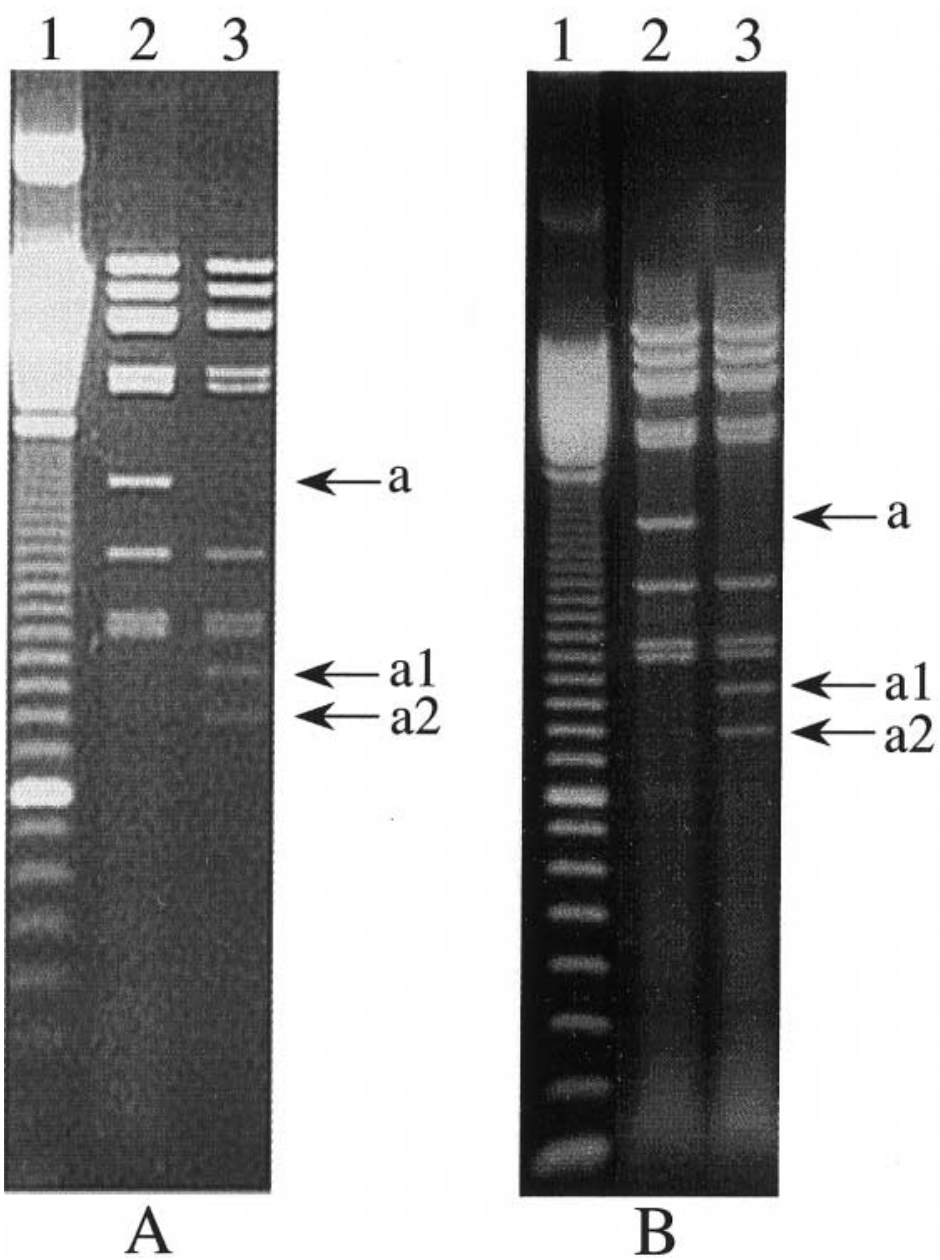

Fig. 1. Restriction endonuclease HindIII digestion pattern of DNA isolated from matured adenoviral suspensions, following the filtration method (A) and of DNA isolated from intracellular adenoviral DNA by Hirt's procedure (B). Lane 1, molecular size marker 100-bp DNA ladder (Amersham Pharmacia Biotech, Piscatway, NJ, USA); 2, DNA from a clinical isolate of adenovirus 7; 3, DNA from a prototype adenovirus 7 .

viral DNA. In contrast DNA isolation from the viral suspension by the filtration method can be completed in only $2 \mathrm{~h}$ and does not require ultracentrifugation [3].

To our knowledge, this is the first report to describe isolation of nucleic acid from viral suspension after concentration by the filtration technique, which has been used generally for concentrating macromolecular solutions of protein, lipids and DNA. Thus, filter systems are designed and characterised by the manufacturers with respect to the cutoff values of mol. wts of macromolecules such as proteins. There are no published data to indicate which filter system and which cutoff value of molecular mass should be selected for rapidly concentrating a suspension of virus of a particular average diameter. The data in the present report establish that the Centricon Plus-20 filter system concentrates viruses of average diameter greater than or equal to that of adenovirus $(75-90 \mathrm{~nm})$. Thus, it is expected that suspensions of other viruses (influenza, $90-100 \mathrm{~nm}$; parainfluenza, $125-200 \mathrm{~nm}$; herpes virus, $180-200 \mathrm{~nm}$; poxviruses, $200-250 \mathrm{~nm}$; cytomegaloviruses, 900-1000 nm) [8] could also be concentrated by following this method and subsequently their nucleic acid could be extracted rapidly for application in various procedures, such as nucleic acid amplification and molecular diagnostics [9].

In nucleic acid amplification-based diagnostic tests for a virus, $\leqslant 0.1 \mathrm{ml}$ of a typical $1-2-\mathrm{ml}$ volume of supplied specimen is used [10]. The present data suggest that if the viral agent in question is $\geqslant 75 \mathrm{~nm}$ in diameter, then the virus concentration in the specimen can be increased at least $10-20$-fold by the filtration method described before application of nucleic acid extraction and subsequent amplification. The procedure will allow 10-20-fold greater amounts of nucleic acid to be available for amplification and detection. This in turn may give positive results for many low-titre specimens that would otherwise be false negative due to the limit of the sensitivity (minimum amount of nucleic acid required in the tested volume) of an assay. During the course of concentration of a specimen, some of the inhibitory agents that are found to copurify with nucleic acid [11] may also filter out. Thus, the use of nucleic acid extracted by the procedure 
described here may also greatly reduce the limitations of nucleic acid amplification-based diagnostics.

This research has been conducted in compliance with all applicable Federal Regulations governing the protection of human subjects in research. This represents report no. 00-21, supported by Department of Defense's Global Emerging Infections System and Bureau of Medicine and Surgery, Department of the Navy, Washington, DC under work unit no. 6609 Navy Environmental Health Center N6854699WR00028 reimbursable. The views expressed in this article are those of the authors and do not reflect the official policy or position of the Department of the Navy, Department of Defense, or the US Government. Approved for public release; distribution unlimited.

\section{References}

1. Hirt B. Selective extraction of polyoma DNA from infected mouse cell cultures. J Mol Biol 1967; 26: 365-369.

2. Poddar SK, Cadden SP, Das J, Maniloff J. Heterogenous progeny viruses are produced by a budding enveloped phage. Intervirology 1985; 23: 208-221.

3. Deryckere F, Burgert H-G. Rapid method for preparing adenovirus DNA. Biotechniques 1997; 22: 868-870.

4. Precious B, Russell WC. Growth, purification and titration of adenoviruses. In: Mahy BWJ (ed) Virology, a practical approach. Oxford: IRL Press. 1985: 193-205.

5. Li Q-G, Wadell G. Analysis of 15 different genome types of adenovirus type 7 isolated on five continents. J Virol 1986; 60: $331-335$.

6. Li Q-G, Zheng Q-J, Liu Y-H, Wadell G. Molecular epidemiology of adenovirus types 3 and 7 isolated from children with pneumonia in Bejing. J Med Virol 1996; 49: 170-177.

7. Graham FL, Prevec L. Manipulation of adenovirus vectors. In: Murray EJ (ed). Gene transfer and expression protocols. Methods in molecular biology, vol 7. Clifton, NJ, Humana Press. 1991: 109-128.

8. Davis BD, Dulbecco R, Eisen HN, Ginsberg HS (eds) Virology In: Microbiology including immunology and molecular genetics, 3rd edn. Hagerstown, MD, Harper and Row. 1980: 8511274.

9. Poddar SK. Symmetric vs asymmetric PCR and molecular beacon probe in the detection of a target gene of adenovirus. Mol Cell Probes 2000; 14: 25-32.

10. Yamada A, Imanishi J, Nakajima E, Nakajima K, Nakajima S. Detection of influenza viruses in throat swab by using polymerase chain reaction. Microbiol Immunol 1991; 35: 259-265.

11. Poddar SK, Sawyer MH, Connor JD. Effect of inhibitors in clinical specimens on Taq and Tth DNA polymerase-based PCR amplification of influenza A virus. J Med Microbiol 1998; 47: $1131-1135$. 